
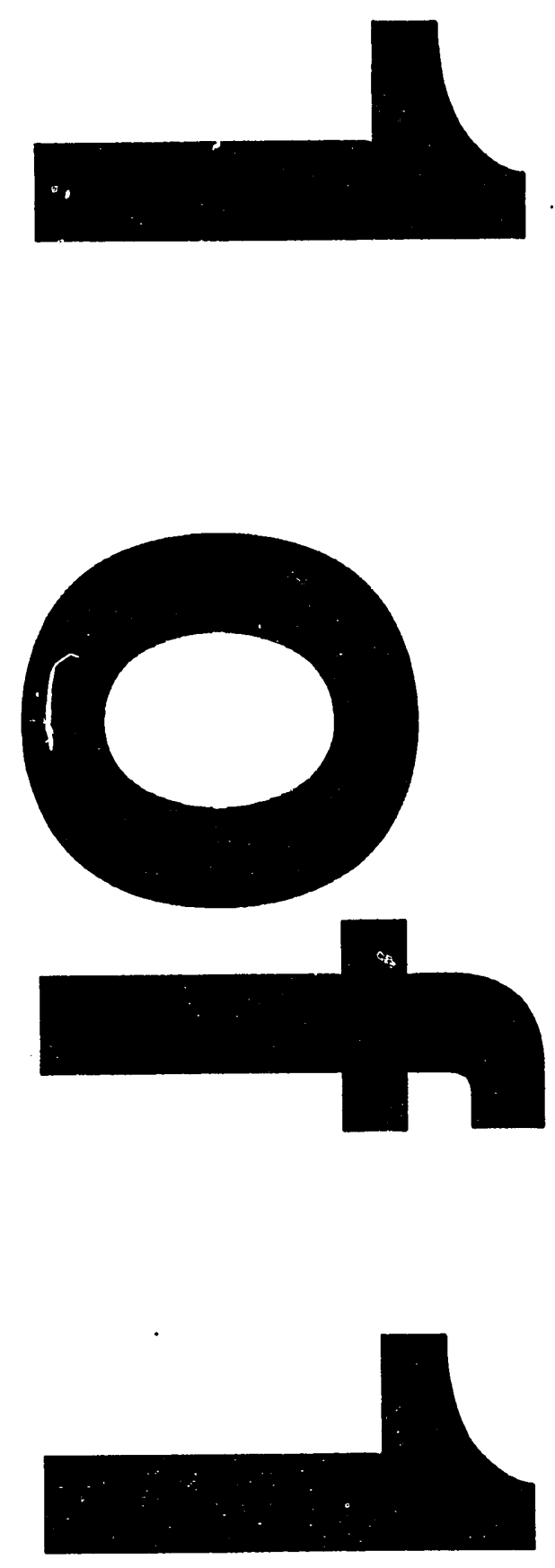


\title{
PARTICLE SIZE DISTRIBUTION OF GROUND ITP WASHED PRECIPITATE FOR ESTIMATING FILTER BOX RADIOACTIVE CESIUM RELEASE DURING TRANSFER
}

by

\author{
L. L. KILPATAICK
}

Westinghouse Savannah River Company

Savannah River Site

Aiken, South Carolina 29808

\section{DISCLAIMER}

This report was prepared as an account of work sponsored by an agency of the United States Government. Neither the United States Government nor any agency thereof, nor any of their employees, makes any warranty, express or implied, or assumes any legal liability or responsibility for the accuracy, completeness, or usefulness of any information, apparatus, product, or praess disclosed, or represents that its use would not infringe privately owned rights. Reference herein to any specific commercial product, process, or service by trade name, trademark, manufacturer, or otherwise does not necessarily constitute or imply its endorsement, recommendation, or favoring by the United States Government or any agency thereof. The views and opinions of atithors expressed herein do not necessarily state or reflect those of the United States Government or any agency thereof.
\end{abstract}

DOE Contract No. DE-AC09-89SR18035

This paper was prepared in connection with work done under the above contract number with the U. S.

Department of Energy. By acceptance of this paper, the publisher and/or recipient acknowledges the U.S.

Government's right to retain a nonexclusive, royalty-free license in and to any copyright covering this paper, along with the right to reproduce and to authorize others to reproduce all or part of the copyrighted paper. 


\section{DISCLAIMER}

This repon was prepared as an account of work sponsored by an agency of the United States Government. Neither the United States Government nor any agency thereof, nor any of their employees, makes any warranty, express or implied, or assumes any legal liability or responsibility for the accuracy, completeness, or usefulness of any information, apparatus, product, or process disclosed, or represents that its use would not infringe privately owned rights. Reference herein to any specific commercial product, process, or service by trade name, trademark, manufacturer, or otherwise does not necessarily constitute or imply its endorsement, recommendation, or favoring by the United States Government or any agency thereof. The views and opinions of authors expressed herein do not necessarily state or reflect those of the United States Government or any agency thereof.

This report has been reproduced directly from the best available copy.

Available to DOE and DOE contractors from the Office of Scientific and Technical Information, P. O. Box 62, Oak Ridge, TN 37831; prices available from (615) $576-8401$.

Available to the public from the National Technical Information Service, U. S. Department of Commerce, 5285 Port Royal Rd., Springfield, VA 22161 


\section{Westinghouse Savannah River Company Savannah River Technology Center}

WS R C-RP-93-1260

Keywords:

ITP, Filter Box Solids

Retention: Lifetime

Page 1 of 9

Date: October 13,93

To: $\quad$ S. D. Fink, 773-A

From: L.L. Kilpatrick, 676-T $\perp \perp / K^{\prime} 10 / 1=/ 23$

Subject: Particle Size Distribution of Ground ITP Washed Precipitate for Estimating Filter Box Radioactive Cesium Release During Transfer

\section{SUMMARY}

ITP washed precipitate, that is dried and ground, has a particle size distribution versus cumulative weight fraction curve (Figure 1 and 3 ) between Powered coal and Filter sand $(1,2)$. The minimum particle size is about 20 microns.

The washed ITP precipitate dries to a hard cake with random cracks. The chip size depends on cake thickness and the' surface it is dried on, such as glass or metal. Chips are generally over one half inch wide and with a few small particles in cracks.

The air velocity to suspend ITP washed solid particles was calculated and plotted (Figure 3).

\section{INTRODUCTION}

The amount and size of particles, generated from a failed ITP silter in its containment box, is desired (TTR No. HLE-TTR-93083) by High Level Waste Engineering (HLWE) to estimate, (knowing the vertical air velocity) the airborne particle leakage rate through various leak paths (defects). The Packaging and Transportation Group (P\&TG) calculated a permissible A2 leakage (4), in the 2 inch thick containment box lid, while the box is in transit to storage. In storage the box pressure differential will be vented to atmosphere through a HEPA filter. 
WSRC-RP-93-1260

Page 2 of 9

\section{EXPERIMENTAL}

Synthetic washed ITP slurry $\left(200 \mathrm{~g}\right.$ ) was oven dried, three days at $60^{\circ}-65^{\circ} \mathrm{C}$ in a pan (see Table (II), to a hard solid that stuck to pan bottom. Between the cracks that formed were a few small particles of unknown size. The solids that were stuck to the pan bottom were pried free and repetitively ground in a mortar and pestle until they all passed through a 40 mesh sieve. This product was then sieved into $50,80,100,170,200,325$ sieve fractions and the results plotted (Table I, Figure 1).

A portion of the fines passing the 325 sieve were further separated by air floatation in a glass tube with fritted botiom( Figure 2). Increasing amounts of air were passed up through tube that floated out increasing fractions of particles after weighing (Table II, Figure 3).

\section{CONCLUSIONS}

- The particle size population of pulverized ITP washed filter solids has a sharply defined boundary (Figures 1 and 3) between Powered coal and Filter sand (1,2).

- Pulverized dried and ground ITP washed precipitate has very few particles less than 20 microns (Figures 1 and 3). A vertical air velocity of $2.2 \mathrm{ft} / \mathrm{min}$ (Figure 2) will disperse ITP particles less than 20 micron.

- Pulverized dried and ground ITP washed precipitate has a 0.5 cumulative weight fraction that solids at about 190 microns. A vertical air velocity of $195 \mathrm{ft} / \mathrm{min}$ (Figure 3) would disperse $50 \%$ of all particles.

- The weight fraction of small particles of any particular size that can be suspended in air after drying ITP washed precipitate depends on, cake thickness, surface dried on, and thermally-induced air velocity (temperature) in the box. 
WSRC-RP-93-1260

Page 3 of 9

TABLE 1

Cumulative Weight Fraction of Washed Ground ITP Solids Retained on Sieve

(Mesh Passed -40 . Retained $+50+80+100+170+200+325)$

\begin{tabular}{|c|c|c|c|c|c|}
\hline $\begin{array}{c}\text { Sieve } \\
\text { Size } \\
\text { Range } \\
-40\end{array}$ & $\begin{array}{c}\text { Wt on } \\
\text { Sieve } \\
9 \\
0\end{array}$ & $\begin{array}{c}\text { Fraction } \\
\text { on } \\
\text { sleve }\end{array}$ & $\begin{array}{l}\text { Passed } \\
\text { Sizo } \\
\text { Mleren }\end{array}$ & $\begin{array}{c}\text { Cumulative } \\
\text { Fraction on } \\
\text { Sleve }\end{array}$ & $\begin{array}{c}\text { Cal Air } \\
\text { Volocity } \\
\text { Et/Mلn }\end{array}$ \\
\hline$-40+50$ & 12.6 & 0.2880 & 420 & 0.288 & 950 \\
\hline$-50+80$ & 9.9 & 0.2265 & 297 & 0.515 & 475 \\
\hline$-80+100$ & 3.2 & 0.0732 & 177 & 0.588 & 169 \\
\hline$-10 \leqslant \leqslant 170$ & 7.3 & 0.1670 & 149 & 0.755 & 120 \\
\hline$-: 70+20 r$ & 4.0 & 0.0915 & 88 & 0.847 & 42 \\
\hline $200+325$ & 4.5 & 0.1030 & 74 & 0.950 & 30 \\
\hline$-325+x<44$ & 2.2 & 0.0530 & 44 & & 10.4 \\
\hline
\end{tabular}


WSRC-RP-93-1260

Page 4 of 9

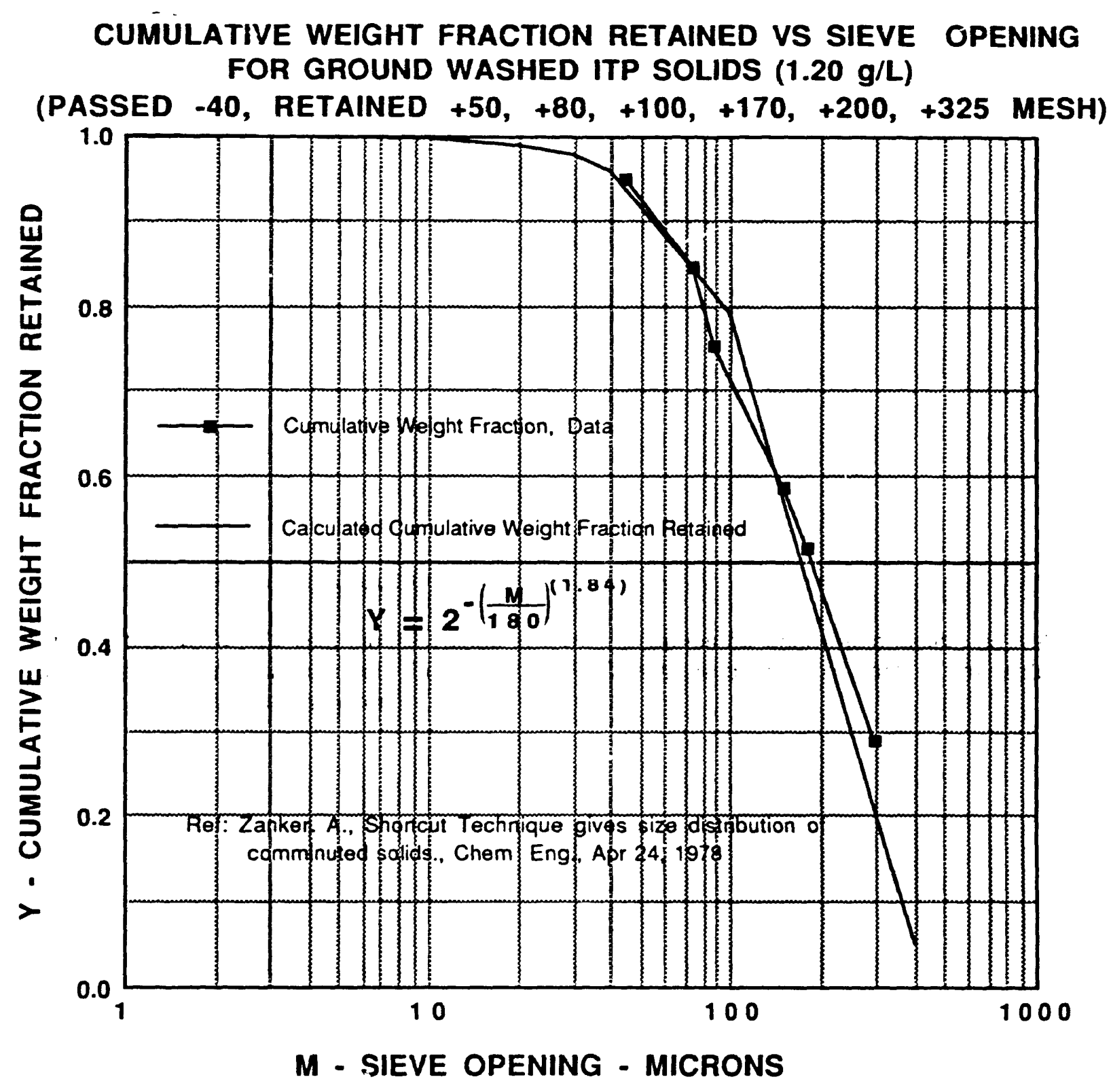

Figure 1 
WSRC-RP-93-1260

Page 5 of 9

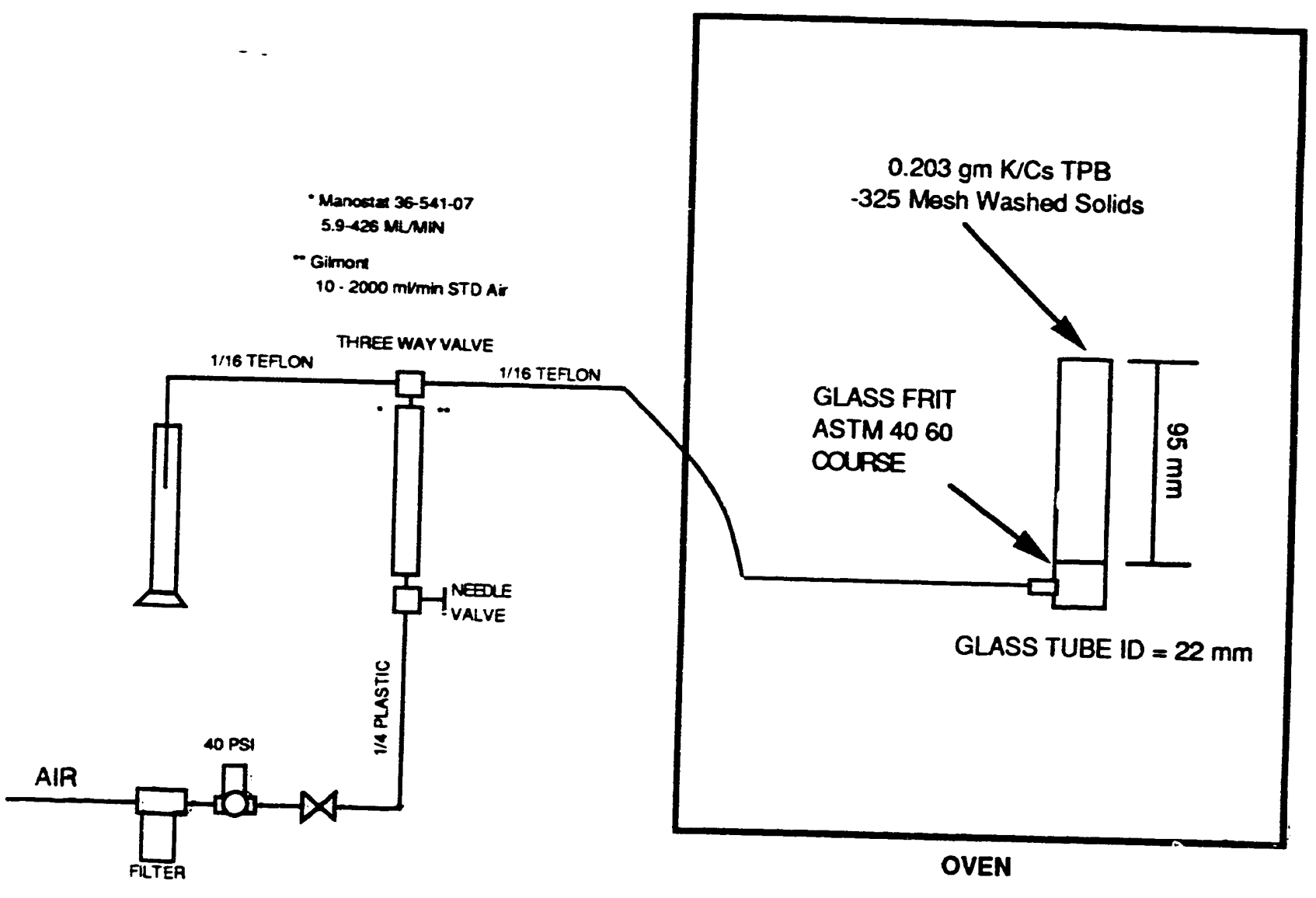

\section{Air Suspension of Washed Ground KTPB Solids For Estimate of Radioactive Cesium Release From ITP Filter Box}

Fig 2 
WSRC-RP-93-1260

Page 6 of 9

\section{TABLE II}

Air Suspension of Washed and Ground KTPB Solids

Iube Tare 39.7516 a. Tube + Beaker Tare 143.1331 a

Temp $40^{\circ} \mathrm{C}$

\begin{tabular}{|c|c|c|c|c|}
\hline $\begin{array}{l}\text { Total } \\
\text { grams }\end{array}$ & $\begin{array}{l}\text { Solids } \\
\text { grams }\end{array}$ & $\mathrm{mL} / \mathrm{min}$ & $\begin{array}{l}\text { Air } \\
\text { ft/min }\end{array}$ & $\begin{array}{l}\text { Suspended } \\
\text { Calc micron }\end{array}$ \\
\hline 143.317 & 0.184 & 5.9 & 0.0493 & 3.01 \\
\hline 143.319 & 0.186 & 24.5 & 0.2046 & 6.12 \\
\hline 143.316 & 0.183 & 57 & 0.4760 & 9.33 \\
\hline 143.317 & 0.184 & 104 & 0.8685 & 12.58 \\
\hline 143.320 & 0.184 & 154 & 1.2861 & 15.30 \\
\hline 143.318 & 0.185 & 206 & 1.7203 & 17.69 \\
\hline 143.319 & 0.186 & 259 & 2.1629 & 19.83 \\
\hline 143.319 & 0.186 & 314 & 2.6222 & 21.83 \\
\hline 143.323 & 0.190 & 370 & 3.0899 & 23.69 \\
\hline 143.322 & $0.18 \theta$ & 426 & 3.5575 & $25.41, \cdots$ \\
\hline 143.308 & 0.175 & 500 & 4.175 & 27.52 \\
\hline 143.289 & 0.158 & 1000 & 8.351 & $\mathbf{3 8 . 6 5}$ \\
\hline 143.182 & 0.0489 & 1500 & 12.53 & 47.59 \\
\hline 143.146 & 0.0129 & 2000 & 16.702 & 54.92 \\
\hline
\end{tabular}


WSRC-RP-93-1260

Page 7 of 9

CUMULATIVE WEIGHT FRACTION ITP SOLIDS RETAINED IN VERTICAL TUBE VS MEASURED AIR VELOCITY TO SUSPEND CALCULATED SIZE PARTICLE $(1.20 \mathrm{gm} / \mathrm{L})$ (ADDED ITP SOLIDS THAT PASSED 325 MESH SCREEN < 44 MICRON)

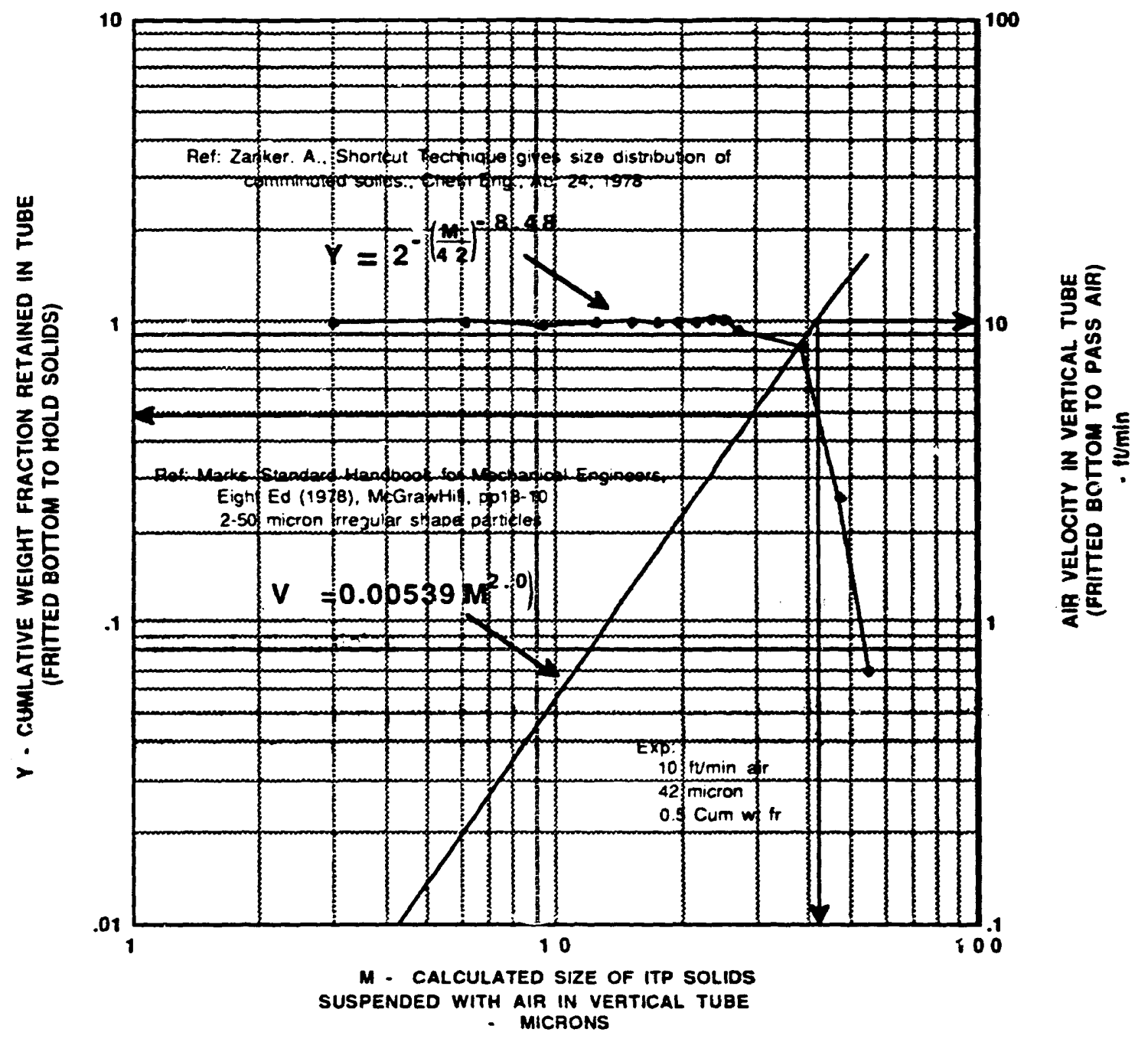

FIGURE 3 
WSRC-RP-93-1260

Page 8 of 9

TABLE III

\section{LABORATORY PREPARATION \\ ITP WASHED SLURRY - 10 wt\% KTPB}

Assumes soluble salts dissolved in $0.9 \mathrm{~L}$ filtrate contained in $1 \mathrm{~L}$ slurry

Add chemicals in following order to $400 \mathrm{~g} \mathrm{H} 2 \mathrm{O}$. Dilute final mixture to $1 \mathrm{~L}(1038 \mathrm{~g})$.

\begin{tabular}{|c|c|c|c|}
\hline CHEMICAL & MOLARITY & MOL WEIGHT (a) & Wt.TOADD (a) \\
\hline $\mathrm{KOH}$ & 0.290 & 56 & 16.24 \\
\hline $\mathrm{Al}(\mathrm{NO} 3) 3 \cdot 9 \mathrm{H} 2 \mathrm{O}$ & 0.0031 & 375 & 1.17 \\
\hline $\mathrm{NaNO} 3$ & 0.0105 & 85 & 0.90 \\
\hline $\mathrm{NaNO} 2$ & 0.0693 & 69 & 4.80 \\
\hline $\mathrm{Na} 2 \mathrm{CO} 3 \cdot 1 \mathrm{H} 2 \mathrm{O}$ & 0.0017 & 123 & 0.22 \\
\hline $\mathrm{Na} 2 \mathrm{SO}_{4}$ & 0.0014 & 142 & 0.20 \\
\hline NaTPB $(.55 \mathrm{M}, 1.045 \mathrm{sg})$ & 0.290 & 342 & 551.0 \\
\hline \multicolumn{4}{|c|}{$\begin{array}{l}\text { Supernate density }=1.0213, \text { Slurry density }=1.03: 5 \mathrm{~g} / \mathrm{L} \\
\text { Density KTPB (Solid) }=1.21 \mathrm{~g} / \mathrm{L}\end{array}$} \\
\hline \multicolumn{4}{|l|}{ Total Solids $=0.129 \mathrm{~kg} / \mathrm{L}$} \\
\hline Total Solids $=12.43 \mathrm{wt} \%$ & & & \\
\hline
\end{tabular}


WSRC-RP-93-1260

Page 9 of 9

\section{REFERENCES}

1. Adam, Zanker, Shortcut technique gives size distribution of comminuted solids, Chem. Eng., April 241978.

2. Perry., J. H. "Chemical Engineers' Handbook", 4th ed., Chap. 8, McGraw-Hill, New York, 1963

3. Marks Handbook (1978), 8th Ed pp 18-10

4. SRT-PTG-93-0075, Maurer R.S., ITP Filter A2 and Heat Generation Calculations.

An A2 is the amount of material in a package, if spilled by accident, that would cause a 5 R commitied effective dose equivalent OR $50 \mathrm{R}$ to an organ OR $15 \mathrm{R}$ to the iens of the eye after 30 minutes exposure BASED ON CERTAIN ACCIDENT SCENARIOS considering all pathways. The DOT leak rate of 10-6 A2/hr under NORMAL Conditions of Transport could give 10 to $1000 \mathrm{mRem}$ annual exposure based on $20 \%$ of $2000 \mathrm{hrs}$ in the sicinity of the package.

For the seal weld of the ITP iilter box. The Packaging and Transportation Group estimates a10-5 A2/hr rather than the 10-6 A2/hr DOT value PROVIDING we administratively limit personnel exposures to $40 \mathrm{hr} / \mathrm{yr}$ (increasing exposure rate by a factor of 10 but cutting exposure time by a factor of 10 from $20 \%$ of $2000 \mathrm{hrs}$ ).

Fable A-1 of 10CFR71 lists the A2 values in terms of Curies for each radionublide as well as the specific activity in Curies/gram. The filter box FDC lists the quantity of each of the isotopes that the box is to be designed for.

\section{QUALITY ASSURANCE}

All work was conducted according to the SRTC Quality Assurance Program. Data for these tests are in Laboratory Notebook DPSTN-3063.

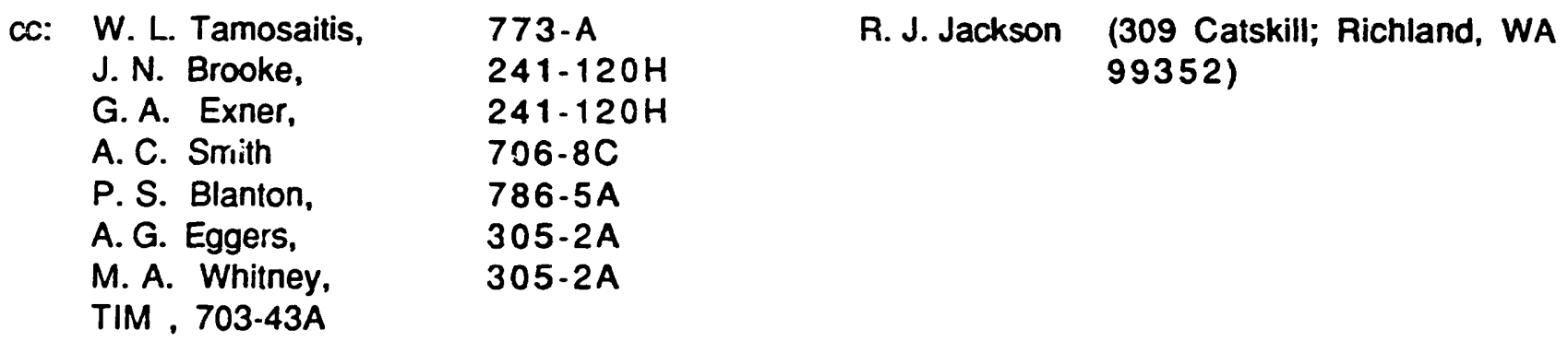



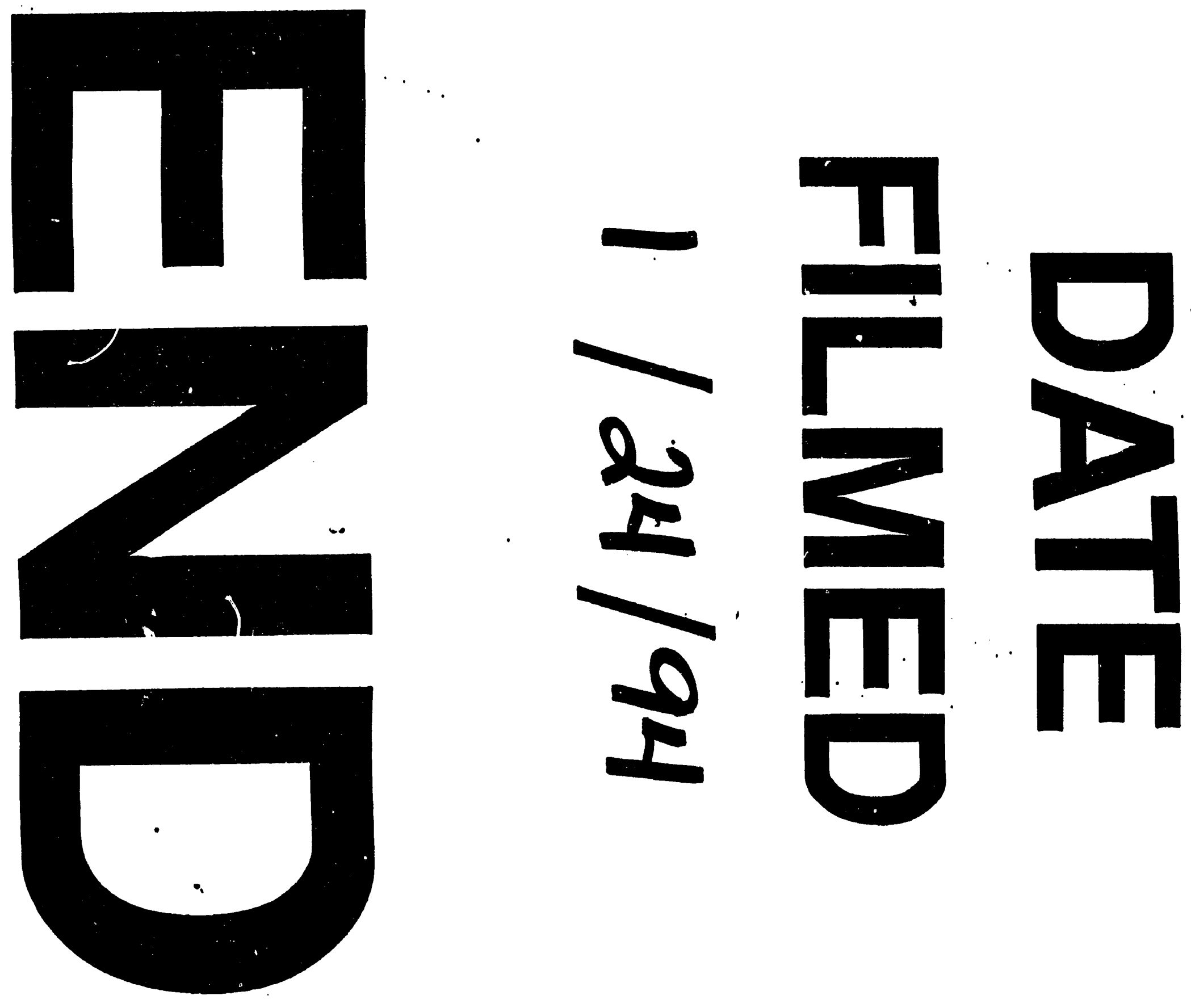